Hal. 223 - 232

\title{
PERBAIKAN PELAPORAN KEUANGAN DESA MELALUI INOVASI SISTEM E-VILLAGE BUDGETING DI KABUPATEN BANYUWANGI
}

\author{
Dewi Ayu Puspita \\ Fakultas Ekonomi dan Bisnis, Universitas Jember \\ dewiayu@unej.ac.id
}

\begin{abstract}
Act No. 6 of 2014 allows village government to be more independent in managing its government system and resources, including its financial and asset management. Village fund allocation sourced from the local government budget of Banyuwangi Regency was increased from Rp 83 billion in 2016 to Rp 148.6 billion in 2017. Village fund from the central government was also increased to Rp 172 billion in 2017. To maintain local budget management, Banyuwangi Government initiated e-village budgeting, a financial application software as an integrated online village budgeting. This research uses descriptive qualitative approach. The units of analysis are Sembulung Village in Cluring District and Jajag Village in Gambiran District, Banyuwangi. Primary and secondary data were sourced from literature study, depth interview, and direct observation using purposive sampling technique. The results show that before implementing e-village budgeting, the village fund management was high in cost and inefficient. The financial statements will automatically be generated by the e-village budgeting system. This system makes financial management easier to perform and is more accountable. As a result, the village fund was used effectively to increase local people's prosperity and quality of life.
\end{abstract}

Keywords: E-village Budgeting, Financial Reporting, Village Fund, Banyuwangi Regency.

\begin{abstract}
Abstrak: Undang-undang Nomor 6 tahun 2014 mengamanatkan pemerintah desa untuk lebih mandiri dalam mengelola pemerintahan dan berbagai sumber daya alam yang dimiliki, termasuk di dalamnya pengelolaan keuangan dan kekayaan milik desa. Alokasi dana desa dari APBD Kabupaten Banyuwangi tahun 2017 mengalami peningkatan dari Rp 83 miliar di tahun 2016 menjadi Rp 148,6 miliar di tahun 2017. Dana desa dari pemerintah pusat untuk 189 desa di Banyuwangi di tahun 2017 mencapai Rp 172,1 miliar. Untuk menjaga pengelolaan anggaran di pemerintah desa, Kabupaten Banyuwangi mempelopori penggunaan software aplikasi keuangan desa yaitu e-village budgeting yang merupakan sistem penganggaran pemerintah desa yang terintegrasi dalam jaringan. Penelitian ini menggunakan pendekatan kualitatif deskriptif. Unit analisis dalam penelitian ini adalah Desa Sembulung, Kecamatan Cluring dan Desa Jajag, Kecamatan Gambiran Kabupaten Banyuwangi. Data primer dan sekunder diperoleh dari studi literatur, wawancara mendalam, dan observasi menggunakan teknik purposive sampling. Hasil penelitian menunjukkan bahwa sebelum adanya e-village budgeting, pengelolaan dana desa membutuhkan biaya yang tinggi dan tidak efisien. Laporan keuangan secara otomatis akan dihasilkan oleh sistem e-village budgeting. Implementasi e-village budgeting membuat pengelolaan dana desa menjadi lebih mudah dan akuntabel. Dana desa dapat digunakan sesuai sasaran untuk meningkatkan kemakmuran dan kualitas hidup masyarakat.
\end{abstract}

Kata Kunci: E-village Budgeting, Dana Desa, Pelaporan Keuangan, Kabupaten Bayuwangi. 


\section{Pendahuluan}

Peraturan Pemerintah No. 72 tahun 2005 Pasal 68 tentang Sumber Pendapatan Desa, "Sumber pendapatan desa terdiri dari : Pendapatan asli desa, terdiri dari hasil usaha desa, hasil kekayaan desa, hasil swadaya dan partisipasi, hasil gotong royong, dan lain-lain pendapatan asli desa yang sah; bagi hasil pajak daerah Kabupaten/Kota paling sedikit 10\% (sepuluh per seratus) untuk desa dan dari retribusi Kabupaten/Kota sebagian diperuntukkan bagi desa; bagian dari dana perimbangan keuangan pusat dan daerah yang diterima oleh Kabupaten/Kota untuk Desa paling sedikit 10\% (sepuluh per seratus), yang pembagiannya untuk setiap Desa secara proporsional yang merupakan alokasi dana desa; bantuan keuangan dari Pemerintah, Pemerintah Provinsi, dan Pemerintah Kabupaten/Kota dalam rangka pelaksanaan urusan pemerintahan; hibah dan sumbangan dari pihak ketiga yang tidak mengikat." Dalam implementasinya, masih sering terjadi beberapa penyelewengan penggunaan anggaran yang berakibat banyak aparat desa yang terkena jeratan hukum. Penyelewengan disebabkan karena desa masih belum memiliki sistem keuangan yang terpadu dan terintegrasi, sehingga pemerintah kabupaten/Kota tidak dapat mengawasi pelaporan keuangan desa dengan optimal.

Demi meminimalisir kecurangan yang terjadi di desa, diperlukan suatu langkah perbaikan dalam pelaporan keuangan desa melalui sebuah sistem yang terpadu, terintegrasi serta dapat dimonitor (Noor, 2013). Salah satu sistem yang terpadu dan terintegrasi dalam pelaporan keuangan desa, adalah sistem e-village Budgetting yang telah diterapkan serentak di 189 desa di kabupaten Banyuwangi pada tahun 2015. Sistem ini merupakan inovasi dari Kabupaten Banyuwangi dalam pelaporan keuangan. E-village budgetting merupakan sistem penganggaran pemerintah desa yang terintegrasi dalam jaringan, atau online yang telah diterapkan di Kabupaten Banyuwangi sebagai sarana menuju transparansi penganggaran dan monitoring pembangunan di desa.

Berdasarkan fakta tersebut, maka sangat diperlukan penelitian mengenai revolusi pelaporan keuangan desa sampai diterapkannya e-Village Budgetting di Kabupaten Banyuwangi. Penelitian tersebut bertujuan untuk mengetahui implementasi dan pengaruh penerapan sistem e-Village Budgetting dalam pelaporan keuangan desa di Kabupaten Banyuwangi. 


\section{Metode Penelitian}

Jenis penelitian yang akan digunakan adalah penelitian survey, kualitatif deskriptif yang akan dilaksanakan di desa yaitu Desa Sembulung Kecamatan Cluring dan Desa Jajag Kecamatan Gambiran Kabupaten Banyuwangi. Data primer dan sekunder akan dianalisis dengan menggunakan metode deskriptif. Tahapan penelitian yang dilakukan meliputi dua tahap. Tahap pertama melakukan studi lapangan/survei digunakan untuk menemukan mengungkap, mengurai permasalahan pertanggungjawaban dan kegunaan pelaporan keuangan desa bagi pihak terkait. Tahapan berikutnya mengevaluasi penggunan sistem e-village budgeting dalam menghasilkan pelaporan keuangan desa Jajag Kecamatan Gambiran dan Desa Sembulung Kecamatan Cluring Kabupaten Banyuwangi.

\section{Hasil dan Pembahasan}

\section{E-Village Budgeting Sebagai Implementasi UU No. 6 tahun 2014 Tentang Desa}

UU No. 6 Tahun 2014 tentang Desa memberi jaminan yang lebih pasti bahwa setiap desa akan menerima dana dari pemerintah melalui anggaran Negara dan daerah yang jumlahnya berlipat, jauh di atas jumlah yang selama ini tersedia di anggaran desa. Kebijakan peraturan yang baru ini memiliki konsekuensi terhadap proses pengelolaannya yang seharusnya dilaksanakan secara profesional, efektif, dan efisien, serta akuntabel yang didasarkan pada prinsip-prinsip manajemen publik yang baik agar terhindarkan dari resiko terjadinya penyimpangan, penyelewengan, dan korupsi (Muluk, 2008). Seiring meningkatnya dana desa dari pemerintah pusat dan alokasi dana desa (ADD) dari Pemerintah Kabupaten, dibutuhkan suatu sistem yang bisa mengatur alokasi anggaran desa.

Pemerintah Kabupaten Banyuwangi telah memulai bagaimana mengawal anggaran desa agar bisa dimanfaatkan secara optimal, mulai dari perencanaan, pelaksanaan penggunaan anggaran desa, sampai pelaporan penggunaan anggaran desa telah menggunakan sistem penganggaran berbasis online. Pemerintah Kabupaten Banyuwangi menerapkan sistem e-village budgeting yang merupakan sistem penganggaran desa yang terintegrasi dalam jaringan (daring). E-village budgeting sistem berbasis online yang pertama di Jawa Timur dan baru efektif digunakan di Kabupaten Banyuwangi tahun 2015, dimana semua anggaran dan program desa terintegrasi secara online. 


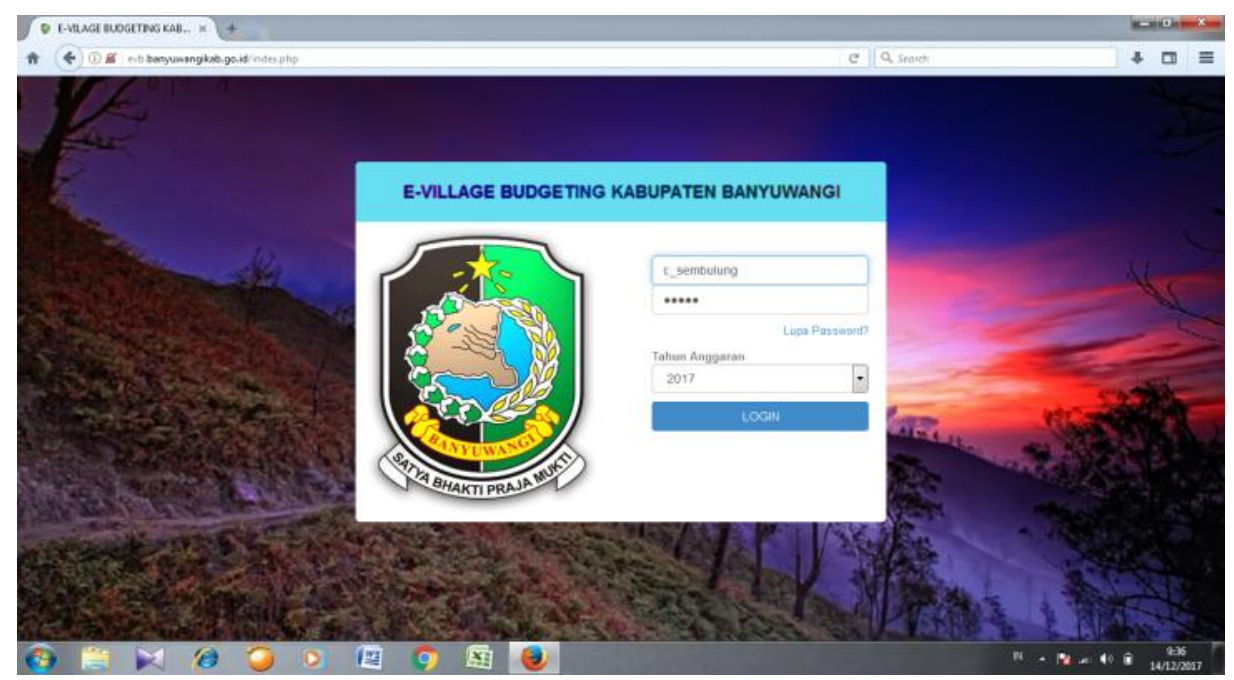

Gambar 1. Homepage E-Village Budgeting Kab. Banyuwangi

\section{Siklus Pelaporan Keuangan Desa Melalui E-Village Budgeting}

Siklus pembangunan desa di Desa Sembulung Kecamatan Cluring dan Desa Jajag Kecamatan Gambiran Kabupaten Banyuwangi pengelolaan keuangannya menggunakan sistem berbasis online yaitu e-village budgeting yang sistemnya telah sesuai dengan UU No.6 Tahun 2014, dimulai dari tahap perencanaan dengan pembuatan RKPDesa dan APBDesa yang dibuat dengan e-VB, kemudian dilanjutkan dengan pelaksanaan pembangunan desa yang melibatkan seluruh masyarakat desa dan selama proses pembangunan desa, serta hasil pembangunan desa harus dilaporkan melalui e-VB, selanjutnya penyampaian pertanggungjawaban laporan keuangan penggunaan anggaran desa harus diunggah di sistem e-VB yang nantinya akan dievaluasi oleh pihak kecamatan, DPMD, BPKAD, dan BPK melalui sistem tersebut.

Terkait dengan Siklus Pelaporan keuangan Desa, mulai dari tahap perencanaan, tahap penatausahaan, tahap pelaporan, sampai pada tahap evaluasi.

1. Tahap Perencanaan dengan E-Village Budgeting

Di Desa Sembulung maupun Desa Jajag konsep perencanaan desa telah sesuai dengan UU No.6 Tahun 2014 tentang Desa dan dilakukan dengan sistem evillage budgeting. Pada tahap perencanaan, dalam sistem e-VB perlu memilih pada modul perencanaan terlebih dahulu untuk dapat mengunggah atau memasukkan semua data terkait dengan perencanaan pembangunan desa. 


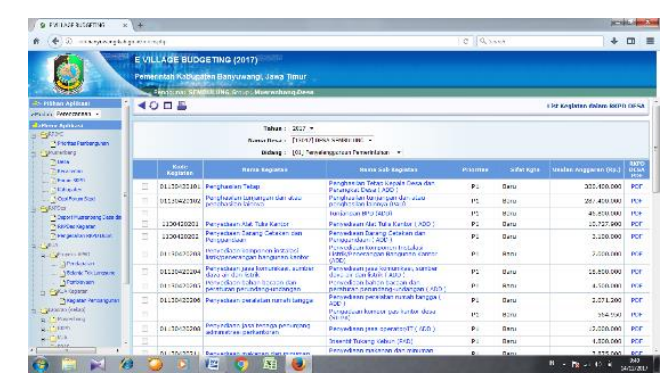

a. Sekretaris Desa menyusun RKPDesa dan RAPBDesa yang disetujui Kepala Desa sebagai dasar disahkannya APBDesa oleh Camat. Sehingga agar camat dan Sekretaris Kecamatan bisa mengetahui isi dari RKPDesa \& RAPBDesa maka Sekdes mengunggah ke sistem e-VB untuk nantinya diperiksa dan diverifikasi oleh pihak Kecamatan, yaitu Camat dan Sekretaris Camat yang pada akhirnya akan disahkan oleh Camat sebagai APBDesa.

b. Setelah APBDesa disahkan oleh Camat secara manual maupun secara online pada sistem e-VB, kemudian Sekdes mengajukan RKPDesa dan APBDesa kepada DPMD dan BPKAD Kabupaten Banyuwangi untuk pencairan keuangan desa yang bersumber dari dana desa (DD) dan alokasi dana desa (ADD).

c. DPMD dan BPKAD Kabupaten Banyuwangi memeriksa dan mengevaluasi RKPDesa dan APBDesa melalui sistem e-VB. Dari e-VB, BPMD dan BPKAD mengetahui apakah RKPDesa dan APBdesa telah disahkan atau belum oleh Camat. RKPDesa dan APBDesa yang belum disahkan oleh Camat tidak dapat melakukan pencairan keuangan desa yang bersumber dari DD dan ADD.

d. Jika semua data terpenuhi oleh Desa maka DD dan ADD akan ditransfer oleh BPKAD ke rekening kas desa.

2. Tahap Pelaksanaan dan Penatausahaan dengan E-Village Budgeting

Dalam merealisasikan APBDesa, Kepala Desa bertindak sebagai koordinator kegiatan yang dilaksanakan perangkat desa dan/atau unsur masyarakat desa. Semua pelaksanaan kegiatan pembangunan desa, pemberdayaan masyarakat desa, dan kegiatan lainnya di Desa Sembulung dan Desa Jajag harus melalui tahapan pemrosesan sistem e-VB yang sesuai dengan PP No. 43 Tahun 2014.

a. Pelaksana kegiatan ditunjuk oleh Kepala Desa sebagai PIC dalam kegiatan pembangunan desa.

b. Pelaksana kegiatan (PK) mengajukan pendanaan kegiatan yang telah dianggarkan di APBDesa dan sudah ada di sistem e-VB nama kegiatan dan jumlah dana yang dianggarkan. 
c. Pelaksana Kegiatan mengajukan pencairan dana ke Bendahara desa disertai dengan rencana anggaran biaya kegiatan.

d. Bendahara Desa mencatat semua belanja yang dibutuhkan oleh pelaksana kegiatan dengan pengajuan surat permintaan pembayaran (SPP) desa di sistem e-VB yang nantinya apakah akan diverifikasi dan diotorisasi oleh Kepala Desa.

e. Jika pengajuan SPP desa terkait belanja pelaksanaan kegiatan desa telah diverifikasi dan diotorisasi Kepala Desa maka Bendahara desa dan pelaksana kegiatan dapat melihat di sistem e-VB tentang status SPP.

f. Setelah SPP diotorisasi Kepala Desa, baru kemudian bendahara melakukan pengeluaran keuangan desa melalui rekening kas desa. Pengeluaran tersebut dicatat oleh Bendahara dalam sistem e-VB modul penatausahaan tentang rekening Bank.

g. Terkait dengan pengeluaran keuangan desa untuk belanja kegiatan desa maka bendahara desa harus melakukan pemungutan pajak penghasilan dan pajak lainnya, serta harus mencatat pemungutan pajak dalam sistem e-VB modul penatausahaan di buku kas umum.

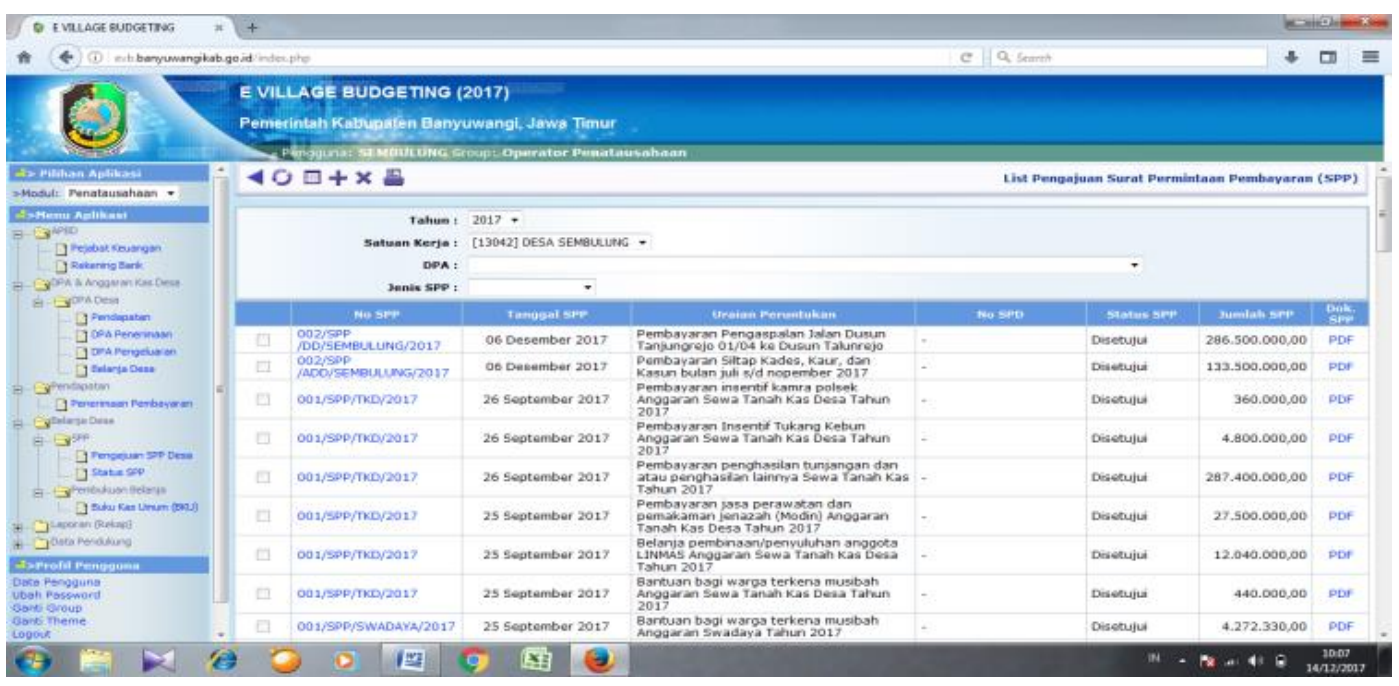

Gambar 2. Tampilan Data per Desa E-Village Budgeting Kab. Banyuwangi

3. Tahap Pelaporan Keuangan Desa dan Pertanggungjawaban dengan EVillage Budgeting

PP No. 43 Tahun 2014 mengatur tata cara pelaporan keuangan desa yang wajib dilakukan oleh Kepala Desa. Kepala Desa diwajibkan menyampaikan laporan realisasi pelaksanaan APBDesa berupa laporan keuangan semesteran dan laporan keuangan tahunan serta laporan pertanggungjawaban. Dengan menggunakan 
sistem e-VB di Desa Sembulung dan Desa Jajag, semua pencatatan penerimaan dan pengeluaran yang dilakukan oleh bendahara desa secara otomatis sistem e-VB akan menghasilkan suatu laporan keuangan, baik itu laporan realisasi anggaran semesteran maupun laporan realisasi anggaran tahunan. Hasil laporan keuangan tersebut tergantung pada penatausahaan setiap penerimaan dan pengeluaran anggaran desa yang dilakukan bendahara desa. Laporan realisasi anggaran semesteran maupun laporan realisasi anggaran tahunan yang dihasilkan secara otomatis oleh sistem e-VB di Desa Sembulung dan Desa Jajag melalui beberapa tahap pelaporan dan pertanggungjawaban, yaitu:

1. Kepala Desa Sembulung dan Desa Jajag menyampaikan laporan realisasi anggaran semesteran dan laporan pertanggungjawaban semesteran kepada Camat, DPMD, dan BPKAD untuk dapat memperoleh pencairan anggaran desa di tahap dua. Jika tidak ada kedua laporan tersebut maka desa tidak dapat memperoleh pencairan anggaran desa tahap selanjutnya.

2. Di akhir tahun, Kepala Desa menyampaikan laporan realisasi anggaran tahunan dan laporan pertanggungjawaban kepada Camat dan DPMD atas penggunaan anggaran desa selama satu tahun APBDesa. Penyampaian kedua laporan tersebut dilakukan secara manual dan melalui sistem e-VB.

3. Hasil laporan realisasi pelaksanaan APBDesa diinformasikan kepada masyarakat secara tertulis dan dengan sarana media informasi yang mudah diakses masyarakat, seperti papan pengumuman balai desa, banner-banner yang dipasang di pertigaan dan perempatan jalan-jalan desa Sembulung dan desa Jajag.

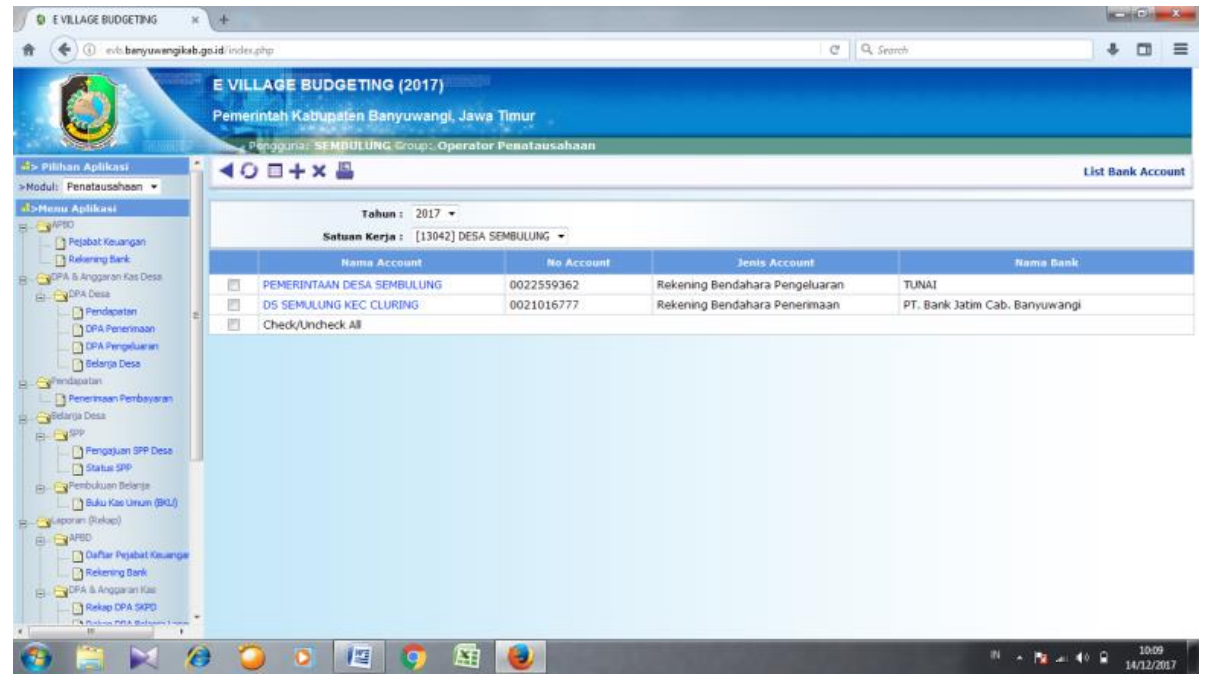

Gambar 2. Tampilan Data per Desa E-Village Budgeting Kab. Banyuwangi 


\section{Pengawasan Pelaporan Keuangan Desa Melalui E-Village Budgeting}

UU No.6 Tahun 2014 meletakkan prinsip dasar untuk penyelenggaraan pengawasan dan pemantauan pembangunan desa yang meliputi, pengawasan supra-desa (downward accountability) dan pengawasan dari masyarakat (upward accountabily). Di Kabupaten Banyuwangi pengawasan supra-desa dari Pemerintah Kabupaten dilakukan mulai dari pihak Kecamatan, yaitu Camat dan Sekretaris Camat yang bisa mengawasi langsung dari laporan realisasi anggaran desa di sistem e-VB dan dari laporan pertanggungjawaban yang disampaikan langsung oleh Kepala Desa kepada Camat. Selanjutnya pengawasan dilakukan pihak Kabupaten yaitu Dinas Pemberdayaan Masyarakat dan Desa (DPMD) dan Badan Pengelolaan Keuangan Aset Daerah (BPKAD) mengawasi laporan realisasi anggaran desa dari sistem e-VB dan laporan pertanggungjawaban yang disampaikan langsung oleh Kepala Desa. Laporan realisasi anggaran desa dan laporan pertanggungjawaban yang disampaikan ke DPMD dan BPKAD nantinya sebagai dasar untuk pencairan anggaran desa selanjutnya. Pengawasan supra-desa dari Pemerintah Pusat biasanya dilakukan oleh BPK atau BPKP.

Pengawasan selanjutnya adalah dari pengawasan dari masyarakat (upward accountabily) terutama masyarakat desa yang menikmati secara langsung hasil dan manfaat dari anggaran desa yang semakin besar nilainya karena adanya dana desa dari APBN. Pengawasan dari masyarakat hanya dilakukan melalui laporan realisasi APBDesa yang diinformasikan di papan pengumuman balai desa, banner-banner yang dipasang di pertigaan dan perempatan jalan-jalan desa sembulung dan desa Jajag, serta melalui hasil pembangunan desa, hasil pemberdayaan masyarakat desa, dan hasil dari kegiatan desa lainnya.

\section{Kesimpulan}

Seiring dengan kemajuan teknologi yang berkembang pesat, semua transaksi telah dilakukan secara online. Kabupaten banyuwangi mencoba sesuatu yang baru yang berbeda dengan yang lain melalui sebuah inovasi sistem yang berbasis online yaitu e-village budgeting (e-VB), dimana semua anggaran dan program desa terintegrasi secara online. e-village budgeting merupakan sebuah inovasi dari Kabupaten Banyuwangi yang berusaha menjawab permasalahan terkait tata kelola keuangan desa yang sering tidak tertib administrasi dan rawan akan penyimpangan anggaran. Dalam pengelolaan pemerintah desa di Kabupaten Banyuwangi terdapat beberapa tahap yang harus dilakukan pemerintah desa terkait dengan sistem 
pelaporan keuangan desa sebagai wujud pertanggungjawaban terhadap penggunaan anggaran desa yang diperoleh dari dana desa dan alokasi dana desa, yaitu tahap perencanaan, tahap pelaksanaan dan penatausahaan, serta tahap pelaporan keuangan desa dan pertanggungjawaban. Tahap perencanaan, dimana data RKPDesa dan RAPBDesa diunggah ke dalam sistem e-VB sebagai dasar menjadi sebuah APBDesa. Kemudian tahap pelaksanaan dan penatausahaan, dimana setiap penerimaan dan pengeluaran dari anggaran desa dicatat dalam sistem e-VB yang nantinya akan menghasilkan sebuah pelaporan keuangan desa. Tahap terakhir adalah tahap pelaporan keuangan desa dan pertanggungjawaban, dimana laporan keuangan desa secara otomatis akan dihasilkan dari tahap penatausahaan. Sedangkan pertanggungjawaban pelaporan keuangan desa disampaikan secara langsung oleh Kepala Desa kepada Camat, Dinas Pemberdayaan Masyarakat dan Desa (DPMD), dan Badan Pengelolaan Keuangan dan Aset Daerah (BPKAD).

\section{Saran}

Seiring dengan inovasi baru dari Kabupaten Banyuwangi e-village budgeting (e-VB), semua transaksi yang terkait dengan pelaporan keuangan dilakukan secara online, sehingga perlu adanya sumber daya manusia (SDM) yang berkualitas sebagai tim pelaksana e-VB. Kualitas SDM yang baik sebagai tim pelaksana e-VB berpengaruh terhadap koordinasi dalam penyusunan anggaran sampai pembuatan laporan keuangan. Jika penyusunan laporan keuangan desa mengalami keterlambatan maka pencairan dana desa dan alokasi dana desa tahap selanjutnya akan mengalami keterlambatan yang secara langsung akan berdampak pula pada keterlambatan kegiatan desa yang telah direncanakan saat Musrenbangdes. Peningkatan kualitas SDM bisa dilakukan dengan mengadakan pendidikan dan pelatihan secara rutin pada tim pelaksana e-VB dari masing-masing desa di Kabupaten Banyuwangi. Selain itu sistem online e-VB sampai saat ini tidak dapat diakses oleh masyarakat umum, terutama masyarakat desa di Kabupaten Banyuwangi, sehingga diharapkan e-VB dapat diakses informasi mengenai pengelolaan keuangan desa untuk meningkatkan transparansi sebagai wujud pertanggungjawaban terhadap masyarakat desa.

Penelitian selanjutnya disarankan dapat meneliti mengenai akuntabilitas atas seluruh pendapatan desa yang diperoleh, yaitu dari pendapatan asli desa, BUMDesa, dan lainnya. 


\section{Daftar Referensi}

Kementerian Keuangan. 2015. Kebijakan Umum Dana Desa (Berdasarkan UU Nomor 6 Tahun 2014 dan PP Nomor 60 Tahun 2014. Jakarta.

Peraturan Pemerintah Republik Indonesia Nomor 43 tahun 2014 Peraturan Pelaksanaan Undang Undang Nomor 6 Tahun 2014 Tentang Desa. 30 Mei 2014. Lembaran Negara Republik Indonesia Tahun 2014 Nomor 123. Jakarta.

Muluk, M.R. Khairul. 2008. Knowledge Management: Kunci Sukses Inovasi Pemerintah Daerah. Malang: Bayumedia.

Noor, Irwan. 2013. Desain Inovasi Pemerintahan Daerah. Malang: UB Press.

Pemerintah Kabupaten Banyuwangi. 2011. Peraturan Daerah Kabupaten Banyuwangi nomor 18 tahun 2011 tentang Sumber Pendapatan Desa. Banyuwangi

Pemerintah Kabupaten Banyuwangi. 2016. 189 Desa di Banyuwangi Telah Terapkan EVillage Budgeting. (Online) (http://banyuwangikab.go.id/berita-daerah/189-desadi-banyuwangi-telah-terapkan-e-village-budgeting.html diakses 9 April 2017)

Pemerintah Indonesia. 2005. Peraturan Pemerintah nomor 72 tahun 2005 tentang Desa. Jakarta

Republik Indonesia. 2004. Undang - Undang Nomor 32 Tahun 2004 tentang Pemerintah Daerah. Jakarta. 